\section{Lo que auguran los astros. Espectáculos, maravillas $Y$ catástrofes en la prensa chilena (1868-1912)}

Valderrama, Lorena \& Ramírez Errázuriz, Verónica. (2020). Lo que auguran los astros. Espectáculos, maravillas y catástrofes en la prensa chilena (1868-1912). Santiago: RIL Editores Universidad Adolfo Ibáñez.

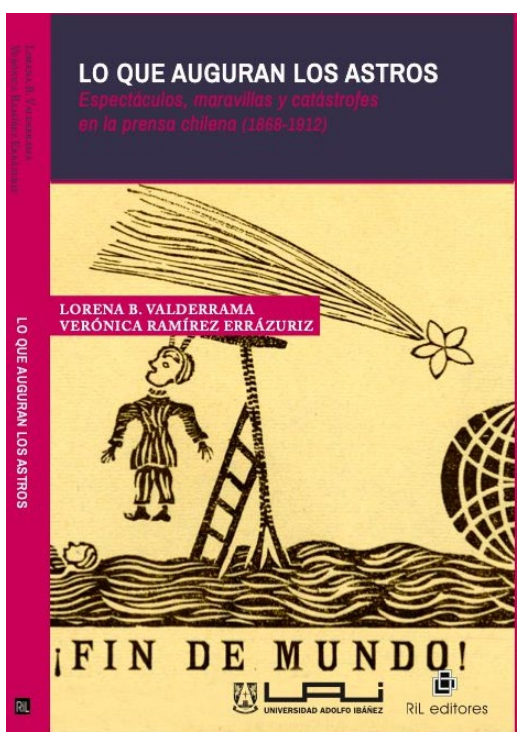

El libro Lo que auguran los astros. Espectáculos, maravillas y catástrofes en la prensa chilena (1868-1912) de las investigadoras Lorena Valderrama y Verónica Ramírez Errázuriz, se inscribe en una zona de los estudios latinoamericanos interdisciplinarios, vinculados a una historia social y cultural de las ciencias, que afortunadamente han venido desarrollándose en el Cono Sur en las últimas dos décadas. Se trata de una zona que estaba ciertamente vacante en la gran área de las humanidades y que emerge como interlocutora obligada de la tradicional historiografía de las ciencias.

Concretamente, el libro analiza la relación entre la prensa y la ciencia en Chile a fines del siglo XIX y principios del $X X$, periodo en que la industria periodística se modernizó y se transformó. El foco está puesto en la divulgación del saber astronómico y, ligado a éste, el sismológico y el meteorológico en la prensa chilena del período, pero el trabajo trasciende, por cierto, el objeto. Porque el abordaje no se circunscribe a los eventos que siempre han incumbido a la historia de las ideas científicas y de las disciplinas consagradas hoy en tanto tales, ni incluye dentro de la noción de "ciencia" al compendio de teorías exitosas que fueron construyendo el acervo de conocimientos aceptados actualmente; sino que, por el contrario, lejos tanto del anacronismo como de la linealidad causal, el libro sintoniza con la amplitud de relaciones sociales y culturales, y la variada red de mediaciones que involucran todo el proceso del desarrollo de las ciencias. Ramírez Errázuriz y Valderrama plantean, desde la introducción, el interés por los ámbitos de producción, circulación, apropiación y transformación del conocimiento científico y de sus interconexiones.

Las autoras buscan atender a esa gran red que trazan los conocimientos científicos, recuperando los lazos entre el ámbito profesional y/o institucional de las disciplinas científicas con los diferentes actores sociales involucrados tanto en la recepción como en la producción misma o en la reelaboración de conocimientos. Uno de los aspectos mejor logrados es el análisis y el foco puesto en la interacción entre expertos, autodidactas y público lector de material científico, la circulación y retroalimentación de saberes, y la ampliación de la noción de ciencia en un sentido social y cultural. También es acertada la forma en que refutan el sentido unidireccional de la noción de "divulgación”, según la cual “los públicos desempeñan un papel pasivo". Señalan las autoras que quienes así conciben la divulgación

entienden la comunicación como una mera transmisión de información desde un emisor a un receptor. Este proceso consistiría en que unas personas clasificadas como expertos llos que saben) generarían conocimiento de forma aislada y, luego, decidirían comunicarlo a otras personas tipificadas como legos, profanos o inexpertos ("los que no saben"), de una forma que fuese comprensible para éstos, dentro de su ignorancia científica y su pasividad epistemológica (p.14).

Por el contrario, Lo que auguran los astros busca "comprender a las audiencias como activas y prestar más atención a las materialidades (soportes y espacios), a las prácticas (de lectura, circulación, traducción, distribución, apropiación), a los procesos de comunicación científica, a la transformación y a la resignificación de los conocimientos y experiencias" (p.15). Atender, por ejemplo, al rol de los divulgadores en la prensa y a la interacción con sus públicos les permite asir de manera más acertada un fenómeno rico y complejo.

En este sentido, el trabajo de análisis sobre la prensa en tanto espacio de divulgación, de representación y de espectacularización de la actividad científica, inscribe también a este libro en el área de los estudios 
sobre prensa gráfica en el siglo XIX y su rol en la conformación de campos disciplinarios y artísticos. La prensa es, desde esta perspectiva, fuente doble: no sólo es el soporte de ciertas temáticas que se relevan como “información”, sino también de manera inseparable- un espacio donde estudiar las formas textuales y discursivas, atravesadas inexorablemente por una historicidad. Cómo se nombran los acontecimientos, cómo se titulan los artículos (cuando, en efecto, se colocan títulos), qué frases, inflexiones del idioma e imágenes se emplean para dar cuenta de ciertos fenómenos es materia significativa, es un dato de la historia y por lo tanto sujeto al análisis de las investigadoras.

Como fuente compleja, casi como compañera prosaica de la novela decimonónica, en la prensa del período efectivamente hablan muchas voces, hay una polifonía desordenada y por momentos orientada controladamente, pero se trata sin dudas de una fuente inagotable para trabajar imaginarios sociales, la noción de discurso social len el sentido de Marc Angenot), las proyecciones futuras que parten de las carencias o miedos del presente, las polémicas y las luchas por las formas de consagración social. En este sentido, las cartas y los relatos testimoniales sobre las catástrofes naturales publicadas en los periódicos, los artículos e ilustraciones incluidas en las revistas culturales y magazines, resultan objeto de atención del libro, así como la circulación de poemarios populares (La Lira Popular), que versificaban diferentes acontecimientos astronómicos y catastróficos.

También es enriquecedora la reconstrucción de trayectorias de sujetos ligados a la sismología, la astronomía, la meteorología, entre otras derivas, tanto sujetos que provenían de la academia o de la educación formal, como otros autodidactas, exogámicos o divulgadores; tanto de origen europeo como latinoamericano. Se focaliza aquí en el análisis de las formas de consagración dentro y fuera del campo estrictamente científico, para los casos de Rudolph Falb, astrónomo austríaco que predijo terremotos y que confrontó con Rudolph Hoernes; de Camille Flammarion; de Arturo Middleton y su trayectoria en la Armada; de Alfred Cooper, entre otros. En muchos casos, las autoras detectan que no importa cuál fuera la formación de base o la pertenencia institucional, todos buscaban ganar prestigio, fama y, por ende, cierta legitimidad social en la prensa y en su actuación para el público, a través de conferencias. Es aquí donde se refuta la idea cristalizada de que los expertos sólo se dirigen a otros pares y debaten sólo entre pares, dado que se detecta el rol que cumplían, el prestigio social y cultural frente a las grandes audiencias y cómo ese prestigio repercutió también, como factor activo, en el campo científico mismo. Además, ese desempeño público contribuyó a la configuración de una imagen de la ciencia particular en la sociedad.

Lo que auguran los astros es el resultado de una sólida investigación en archivos hebdomadarios y del diseño de preguntas pertinentes y sagaces sobre un fenómeno que no sólo toca al desarrollo y circulación de ciertos saberes científicos o al puntual proceso de modernización de la prensa chilena, sino -en un sentido más cabal- a las formas en que la sociedad del pasado lidió con el conocimiento secular y sus derivas.

\section{Soledad Quereilhac}

Profesora Asociada

Universidad de Buenos Aires/Conicet solquereidgmail.com 